Article

\title{
Climate Change Impacts on Sediment Quality of Subalpine Reservoirs: Implications on Management
}

\author{
Marziali Laura ${ }^{1, *}$ (D), Gianni Tartari ${ }^{1}$ (D), Franco Salerno ${ }^{1}$, Lucia Valsecchi ${ }^{1}$, Clara Bravi ${ }^{2}$, \\ Erika Lorenzi ${ }^{3}$, Pietro Genoni ${ }^{3}$ and Licia Guzzella ${ }^{1}$ \\ 1 CNR IRSA, Water Research Institute, Via del Mulino, 19, I-20861 Brugherio (MB), Italy; \\ tartari@irsa.cnr.it (G.T.); salerno@irsa.cnr.it (F.S.); l.valsecchi@irsa.cnr.it (L.V.); guzzella@irsa.cnr.it (L.G.) \\ 2 Lombardy Region, Piazza Città di Lombardia, 1, I-20124 Milano, Italy; clara_bravi@regione.lombardia.it \\ 3 Lombardy Regional Environmental Protection Agency, Via Rosellini, 17, I-20124 Milano, Italy; \\ e.lorenzi@arpalombardia.it (E.L.); p.genoni@arpalombardia.it (P.G.) \\ * Correspondence: marziali@irsa.cnr.it; Tel.: +39-039-21694207
}

Received: 8 August 2017; Accepted: 5 September 2017; Published: 7 September 2017

\begin{abstract}
Reservoirs are characterized by accumulation of sediments where micropollutants may concentrate, with potential toxic effects on downstream river ecosystems. However, sediment management such as flushing is needed to maintain storage capacity. Climate change is expected to increase sediment loads, but potential effects on their quality are scarcely known. In this context, sediment contamination by trace elements $(\mathrm{As}, \mathrm{Cd}, \mathrm{Cr}, \mathrm{Cu}, \mathrm{Hg}, \mathrm{Ni}, \mathrm{Pb}$, and $\mathrm{Zn}$ ) and organics (Polycyclic Aromatic Hydrocarbons PAHs, Polychlorinated Biphenyls PCBs and C $>12$ hydrocarbons) was analyzed in 20 reservoirs located in Italian Central Alps. A strong As and a moderate Cd, $\mathrm{Hg}$ and $\mathrm{Pb}$ enrichment was emphasized by $\mathrm{I}_{\text {geo, }}$, with potential ecotoxicological risk according to Probable Effect Concentration quotients. Sedimentation rate, granulometry, total organic carbon (TOC) and altitude resulted as the main drivers governing pollutant concentrations in sediments. According to climate change models, expected increase of rainfall erosivity will enhance soil erosion and consequently the sediment flow to reservoirs, potentially increasing coarse grain fractions and thus potentially diluting pollutants. Conversely, increased weathering may enhance metal fluxes to reservoirs. Increased vegetation cover will potentially result in higher TOC concentrations, which may contrast contaminant bioavailability and thus toxicity. Our results may provide elements for a proper management of contaminated sediments in a climate change scenario aiming at preserving water quality and ecosystem functioning.
\end{abstract}

Keywords: dams; trace metals; contaminated sediments; desiltation; sedimentation rate

\section{Introduction}

Reservoirs represent a strategic resource [1] which requires careful management of hydraulic networks and dams without neglecting the protection of water quality [2-4]. Reservoirs are typical sites where sediment accumulation is favored and desiltation is needed to maintain water storage capacity, as well as proper functioning and services [5-7]. Anthropic activities influence sediment dynamics in watercourses $[1,8,9]$ and recent works are currently focusing on potential impacts of climate change on sediment loads $[5,10]$. In fact, increasing air temperature and altered rainfall rates will increase soil erosion and will affect the distribution of vegetation in catchments [11-13], leading, in turn, to increased sediment flows [5].

In Northern Italy, there is a huge number of reservoirs (more than 600 in Central Alps), which are mainly used for hydropower generation. Different strategies are used to reduce sediment accumulation, but a common practice is flushing, i.e., the scouring out of deposited sediments using low-level outlets in dams to lower water levels, thereby increasing flow velocities in the reservoir. This technique is 
quite effective for removing huge quantities of sediments in short times, but has strong ecological implications in the river stretches downstream the dams [14]. At first, the physical-mechanical impact may reset the aquatic communities during flushing, but then, after recolonization, ecotoxicological effects may arise on aquatic organisms due to the release of toxic substances from deposited sediments. Recent studies demonstrated that flushing operations create strong variations in physical and chemical parameters such as $\mathrm{pH}$, solid/liquid ratio, redox conditions, temperature and salinity, and these environmental changes lead to the release of contaminants such as trace metals previously accumulated in the reservoir sediments $[3,14]$. In fact, preliminary results showed that reservoir sediments are characterized by high concentrations of trace elements deriving from natural weathering, such as arsenic, with resulting ecotoxicological effects on aquatic organisms [15]. Thus, sediments potentially act as source of contamination which is transferred to the downstream river ecosystems with increased bioavailability and potential toxicity [16]. For these reasons, in Northern Italy, studies on reservoir sediment quality are being carried out, in order to adopt proper management strategies aiming at minimizing the impact of flushing operations on the water bodies downstream the dams and protect aquatic life, as required by the European Water Framework Directive (2000/60/EC).

Considering the increasing importance of reservoirs as water storage in the climate change scenario, important considerations may arise on sediment management issues. A substantial body of research demonstrates the sensitivity of lakes [17] and reservoirs [18] to climate and shows that physical, chemical, and biological lake properties respond rapidly to climate-related changes [17,19-22]. For example, climate-driven fluctuations in lake surface area have been observed in Central Alps during the last 50 years. Salerno et al. [22] found that lakes located $<2500 \mathrm{~m}$ a.s.l. in this Alpine region experienced surface area reduction due to the increased evaporation/precipitation ratio associated with climatic warming, while at higher elevations ( $>2900 \mathrm{~m}$ a.s.l.) lake size has increased as a consequence of glacial retreat. The same authors observed that in Central Alps trends of mean air temperature showed an increase of $0.012{ }^{\circ} \mathrm{C}$ year ${ }^{-1}$ from 1924 to 2007 , which was the same rate observed as a century average for the Alpine region $\left(1.2^{\circ} \mathrm{C}\right)[23,24]$. With regard to precipitation, several studies highlighted differences in Total Precipitation (TP) trends in different zones of the Alps. Whereas stations located north of the ridge present some increases in TP, decreases prevail in the south [23,25-27]. Brugnara et al. [28] performed a high-resolution analysis of precipitation trends in Central Alps over the last century (1922-2009) observing that TP does not seem to change substantially. Despite this absence of trend, the average number of rain days in this region during 1834-1998 shows a significant negative trend in all seasons. Consequently, precipitation intensity has a positive trend [29]. Increasing precipitation intensity has been observed not only in Northern Italy, but also in other parts of the world. This phenomenon is probably related to an intensification of the water cycle due to the temperature increase [30]. Whereas changes in climate and their impacts on morphological characteristics of lakes are well known, less information is available on expected fluxes and dynamics of sediments in lakes and reservoirs as a consequence of climate change.

In this context, the aim of this paper is to depict sediment contamination by trace elements and organics in 20 reservoirs in Italian Central Alps and to identify relations between contaminant concentrations and sediment characteristics potentially affected by climate change. Thus, by inference, results are used to predict potential effects of climate change on reservoir sediment contamination and to suggest directions for their management.

\section{Materials and Methods}

\subsection{Region of Investigation}

The study area is located in the central part of the Alps in Northern Italy (Figure 1). This area has a complex orography characterized by the presence of a northern mountainous and a southern piedmont area. Geologically, the northern part can be divided into two domains (Alpine and Subalpine) separated by a tectonic line called "Linea Insubrica" arranged along the east-west direction. The Alpine 
area is characterized by metamorphic and igneous rocks, with the presence of Holocenic alluvial deposit, while the Subalpine area is composed mainly by calcareous sedimentary rocks (limestone and dolomite) [31]. The mean altitude is $1600-1700 \mathrm{~m}$ a.s.l. in the Alpine area and about $1100 \mathrm{~m}$ a.s.l. in the Subalpine area. In both parts, the mean slope is about 50\% [32]. The climate in the Alpine area is temperate [33,34] with mean annual temperature ranging between 0.8 and $10{ }^{\circ} \mathrm{C}$ and mean annual precipitation of $650-1500 \mathrm{~mm}$. In the Subalpine area, the mean annual temperature is milder $\left(11-13^{\circ} \mathrm{C}\right)$ and precipitation is $690-1200 \mathrm{~mm}$.

In the Alpine area, more than 600 reservoirs are present, among which there are about 175 "large" ones with a surface of $\geq 0.01 \mathrm{~km}^{2}[35,36]$. In our study area, comprised in the Central sector of the Alps, there are 63 "large" reservoirs, distributed between 250 and $2600 \mathrm{~m}$ a.s.l. (Figure 1). These reservoirs are all characterized by hydropower installations and they generally require constant sediment management in order to maintain water storage capacity and flow regulation functioning. In high altitude reservoirs (above $1700 \mathrm{~m}$ a.s.l.), or in reservoirs characterized by large storage capacity and small catchment area, sedimentation rate is very low, thus specific operations for sediment management are generally not needed. In the other cases, flushing operations, as well as sluicing/venting, are mainly carried out for desiltation (about $70 \%$ of these cases). Only in a few cases dredging of coarse material is performed. Of these "large" reservoirs, 20 cases were considered in this study. They all derive from the construction of dams along river courses.

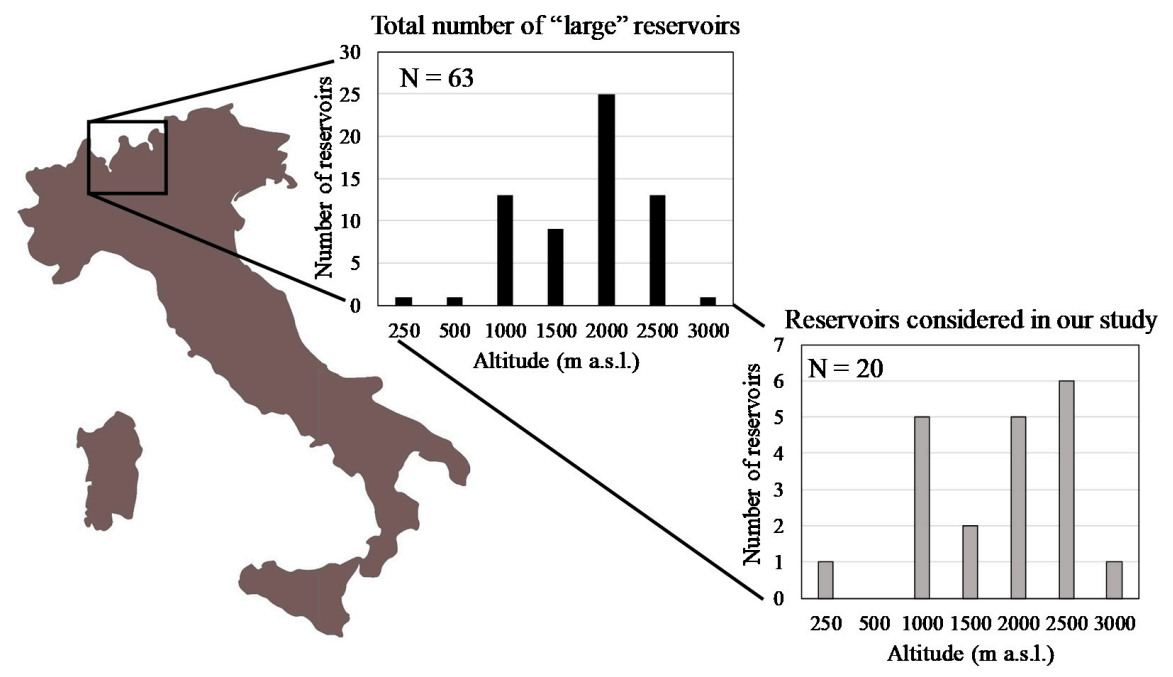

Figure 1. Map of study area in the Central Alps with details about altitudinal distribution of all "large" reservoirs, 20 of which are considered in this study.

\subsection{Sediment Sampling and Analysis}

Sediment samples were collected between 2011 and 2016 in the selected 20 reservoirs with the aim of characterizing sediment characteristics before flushing operations. Detailed information about reservoirs and samplings are omitted because data were collected by private managers of the dams and validated by Italian public institutions responsible of environmental protection.

Different sampling protocols were carried out in each reservoir depending on specific situations: sediments were collected with grabs or corers in 1-9 sampling stations. Sediment cores were divided into 2-5 sections according to core length. Samples were $2 \mathrm{~mm}$ sieved and analyzed for determination of trace elements (As, Cd, Cr, Cu, Hg, Ni, Pb, and Zn), organics (Polycyclic Aromatic Hydrocarbons PAHs, Polychlorinated Biphenyls PCBs and C $>12$ hydrocarbons) and Total Organic Carbon (TOC) following standard protocols used for official monitoring programs (e.g., UNI EN ISO and US-EPA protocols). Analyses were carried out on the finest sediment fractions $(<2 \mathrm{~mm})$, which are responsible for the accumulation of micropollutants in lakes and reservoirs [16,37]. Concentrations are expressed as dry weight (d.w.) on $<2 \mathrm{~mm}$ grain size fraction to reduce the influence of humidity and granulometry 
on total concentrations. Moreover, values of PAHs, PCBs and C > 12 were also normalized to $1 \%$ TOC to reduce the influence of organic carbon on total concentrations.

\subsection{Data Analysis}

Morphometric features of reservoirs (altitude, volume, surface area, maximum depth) were derived by the cadaster of Italian lakes [35]. Sedimentation level (\% volume year ${ }^{-1}$ ) was calculated as annual percent volume of sediments on total reservoir volume, basing on bathymetric profiles (e.g., difference between the maximum volume of storage capacity and the volume estimated in the most recent bathymetric profile). Sedimentation rate $\left(\mathrm{cm} \mathrm{year}^{-1}\right)$ was calculated as thickness of sediment layer $(\mathrm{cm})$ deposited in a year in each reservoir, dividing the actual volume of sediments (estimated with the most recent bathymetric profile) by reservoir maximum water surface and by the number of years from dam construction to the bathymetric relief.

Concerning sediment cores, no vertical trends in pollutant concentrations were found [15], therefore in the following analyses we considered all analyzed sections as different samples.

Considering metal concentrations, for each sample, the Geoaccumulation Index $\left(\mathrm{I}_{\text {geo }}\right)$ was calculated according to the following formula [38]:

$$
\mathrm{I}_{\text {geo }}=\ln \left[\frac{\mathrm{C}_{\text {sample }}}{1.5 \mathrm{C}_{\text {background }}}\right]
$$

where $\mathrm{C}_{\text {sample }}$ is the concentration of the element in the sample, $\mathrm{C}_{\text {background }}$ is the concentration of the median concentrations in shales, and 1.5 is a factor which accounts for natural fluctuations in the content of the element in the environment. $I_{\text {geo }}$ provides a measure of metal pollution intensity of riverine sediments by comparing concentrations to the mean geochemical background [38]. Concerning our case study, we do not have information about metal background concentrations in reservoirs; therefore, we used global baseline levels $\left(C_{\text {background }}\right)$ as suggested by Barbieri [39]. Minimum, maximum and median values of $I_{\text {geo }}$ for each trace element were calculated. $I_{\text {geo }}$ classification follows Barbieri [39].

To analyze the potential toxicity risk for aquatic organisms deriving from sediment contamination, a widespread approach is the calculation of the Probable Effect Concentration Quotients (PECQs) by Long et al. [40], which are obtained by comparing pollutant concentrations to ecotoxicological thresholds (Sediment Quality Guidelines). For each sample, the PECQ was calculated for each pollutant $\mathrm{i}$ according to the following formula [40]:

$$
\mathrm{PECQ}_{\mathrm{i}}=\frac{\left[\mathrm{P}_{\mathrm{i}}\right]}{\mathrm{PEC}_{\mathrm{i}}}
$$

where $\left[\mathrm{P}_{\mathrm{i}}\right]$ is the concentration of the pollutant $\mathrm{i}$ (trace element or organic compound) in the sample and $\mathrm{PEC}_{\mathrm{i}}$ is the Probable Effect Concentration for the pollutant $\mathrm{i}$ according to MacDonald et al. [41], i.e., the concentration above which adverse effects on benthic organisms are likely to occur. For $C>12$, the PEC value of $860 \mathrm{mg} \mathrm{kg}^{-1} \mathrm{~d}$.w. was derived from Marshall et al. [42]. For each sample, the total PECQ (PECQ ${ }_{\text {tot }}$ ) was calculated according to the following formula [40]:

$$
\mathrm{PECQ}_{\mathrm{tot}}=\frac{\sum_{\mathrm{i}}^{\mathrm{n}}\left[\mathrm{P}_{\mathrm{i}}\right] / \mathrm{PEC}_{\mathrm{i}}}{\mathrm{n}}
$$

where $\mathrm{n}$ is the total number of pollutants considered for each sample. PECQ $\mathrm{Q}_{\text {tot }}$ takes into account the risk deriving from mixture of chemical contaminants in sediments. Values of PECQ and PECQ tot above 1 represent potential risk.

To analyze the relations between pollutant concentrations and physical-chemical variables (altitude, volume, surface area, maximum depth, TOC and sedimentation) two separate analyses were carried out because the number of cases with metal concentrations was higher than for organics 
(86 vs. 73 cases). Thus, a Principal Component Analysis (PCA) was carried out considering trace metals (As, $\mathrm{Cd}, \mathrm{Cr}, \mathrm{Cu}, \mathrm{Hg}, \mathrm{Ni}, \mathrm{Pb}$, and $\mathrm{Zn}$ ) as active variables and the physical-chemical variables as supplementary variables. In addition, another PCA was carried out considering organics (PAHs, PCBs and $C>12$ ) as active variables and physical-chemical variables as supplementary variables. Data were $\log$ transformed prior to the analysis. Calculations were carried out using Statistica ${ }^{\mathrm{TM}} 8.0$ software. These analyses allowed finding the main drivers governing reservoir sediment contamination.

\subsection{Climate Change Scenarios}

To predict potential effects of climate change on sediment quality in reservoirs, we based our analysis on published literature. Generally, predictions on soil erosion changes in the future are mainly dependent on modeling future rainfall erosivity (R-factor). $\mathrm{R}$-factor is an average index that measures rainfall kinetic energy and intensity describing the effect of rainfall on sheet and rill erosion [43]. As discussed by many authors, a possible increase of precipitation intensity will bring to enhance the erosive power of rainfall. In this context, Panagos et al. [43] estimated the expected change in $\mathrm{R}$-factors and its impact on soil erosion in Europe during the first half of the 21st century based on the IPCC climate change scenarios (according to the Representative Concentration Pathway of 4.5 (RCP4.5)) [30]. This study focused on the R-factor changes without considering the impact of climate change on vegetation cover. Compared to previous studies, Panagos et al. [43] used as inputs the high-temporal-resolution Rainfall Erosivity Database at European Scale (REDES) and climatic data derived from the WorldClim database, which is set on global climate grids with a spatial resolution of about $1 \mathrm{~km}^{2}$. The temporal scale considered by these authors was more than half a century. The availability of high resolution maps allowed formulating hypotheses on the variations of erosion at 2050, compared to present time (reference year: 2010). These maps were used here to forecast the variations in the sediment yields that will flow to reservoirs in our study area.

With respect to the fluxes of organic matter from the catchments to reservoirs at the end of this century, the maps related to the future climatic scenarios developed by Rubel et al. [10] were used. These authors developed a time series of very high resolution (30 arc-seconds) maps of the well-known Köppen-Geiger climate classification. Methodological details can be found in Rubel et al. [10], while, in the following, we report just the main aspects. Projected climate data for the period 2011-2100 were taken from the Rossby Centre regional atmospheric model [44]. The scenarios were developed according to RCP2.6, corresponding to a moderate increase of temperature of $1.0^{\circ} \mathrm{C}$, and an extreme projection, the RCP8.5, corresponding to a temperature increase of 1.4 for $2046-2065$ and of $1.8^{\circ} \mathrm{C}$ for 2081-2100. The maps cover the entire Alpine region and thus are suitable for our purposes.

\section{Results and Discussion}

\subsection{Contamination of Reservoir Sediments and Toxicity Risk}

The 20 reservoirs considered in this work are predominantly distributed (18 out of 20) between 1000 and $2500 \mathrm{~m}$ a.s.l., as well as the other "large" reservoirs present in the study area (Figure 1). Their morphometry is typical of small/medium reservoirs, with morphometric parameters ranging between 9 and $86 \mathrm{~m}$ for maximum depth, between 0.02 and $2.2 \mathrm{~km}^{2}$ for surface area and between 0.05 and $63 \times 10^{6} \mathrm{~m}^{3}$ for volume (Table 1). Covering a wide geographical, altitudinal and morphometric range, they can be considered representative of Subalpine reservoirs in the Central Alps. These reservoirs are generally affected by high siltation, with a median sedimentation level of $0.41 \%$ and a median sedimentation rate of $5.6 \mathrm{~cm}_{\text {year }}^{-1}$ (Table 1). However, they cover a wide sedimentation range, i.e., from 0.001 to $8.6 \%$ for sedimentation level and from 0.1 to $74 \mathrm{~cm}_{\text {year }}{ }^{-1}$ for sedimentation rate (Figure 2). 

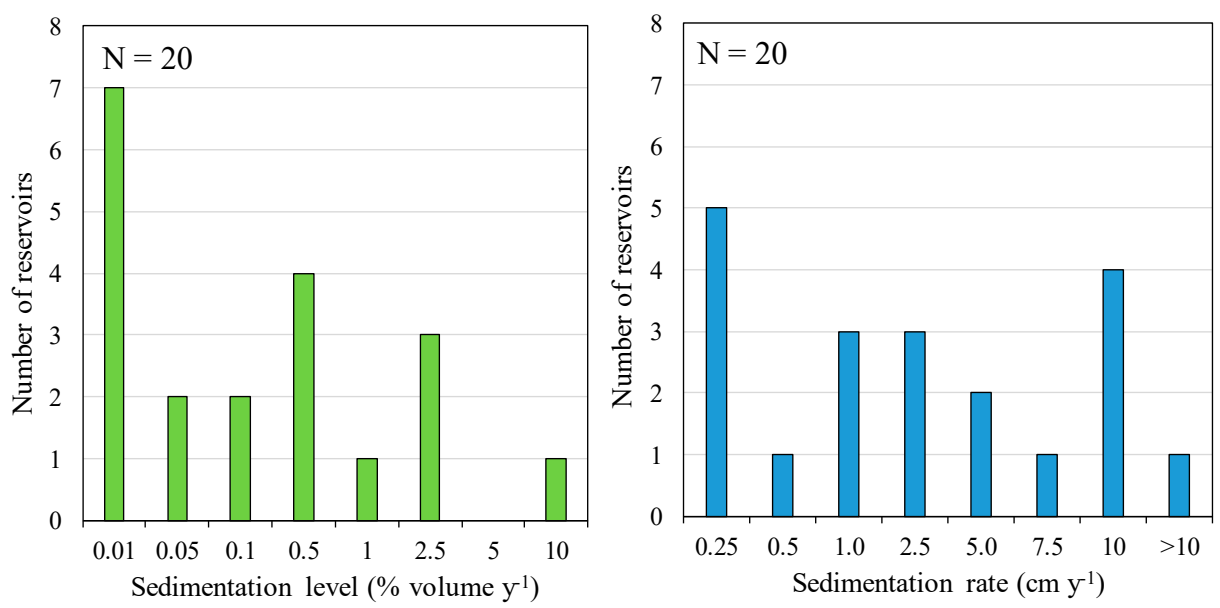

Figure 2. Distribution of sedimentation level (expressed as percent annual sediment volume on total reservoir volume) and sedimentation rate (expressed as thickness of sediments deposited in the reservoir per year) in the 20 reservoirs considered.

Percent fine sediment fraction $(<2 \mathrm{~mm})$, where pollutants are mainly accumulated, constituted generally more than $90 \%$ of the total collected sediments and had a median content of Total Organic Carbon of $108 \mathrm{~g} \mathrm{~kg}^{-1}$ d.w., ranging from 0.06 to $13.0 \mathrm{~g} \mathrm{~kg}^{-1}$ d.w. Contaminant concentrations covered a wide range, with $2-3$ orders of magnitude between minimum and maximum values (Table 1 ).

To measure metal pollution intensity in comparison to concentrations in the geochemical background, $\mathrm{I}_{\text {geo }}$ was calculated (Table 2). According to this parameter, $\mathrm{Cr}, \mathrm{Cu}, \mathrm{Ni}$ and $\mathrm{Zn}$ were not enriched, showing mostly negative values, and concentrations may represent a natural background. $\mathrm{Hg}$, $\mathrm{Pb}$ and $\mathrm{Cd}$ showed peaks comprised between 1 and 2 and may be considered moderately polluted. Lastly, arsenic showed the highest $I_{\text {geo }}$, with values up to 4.6 , showing strong enrichment (strongly to extremely polluted sediments). Igeo does not provide any information about the origin of trace elements, which may be both geogenic and/or anthropogenic. According to the presence of anthropogenic activities in the reservoir catchments, in most cases the analyzed elements are supposed to derive from natural weathering. Indeed, fine sediments accumulated into reservoirs may concentrate pollutants, preventing their transport downstream $[3,16]$.

For what concerns organics, PCBs are synthesis compounds classified as Persistent Organic Pollutants (POPs), therefore they can be found in sediments as effect of anthropogenic activities and/or long-distance transport [45-47]. On the contrary, both PAHs and C $>12$ may derive from both natural and anthropogenic source, originating from petrogenic, pyrogenic or natural processes [47-50]. For these organics, a background cannot be defined.

To assess the potential ecotoxicological risk for aquatic organisms deriving from exposure to contaminated sediments, concentrations were compared to Probable Effect Concentrations (PECs, Table 1). Median values did not exceed these thresholds, but, in some cases, maximum values were higher. The most striking exceedance was found for As, with maximum values exceeding the PEC more than 20 times (Table 3). The maximum values of $\mathrm{Hg}$ and $\mathrm{Pb}$ were just over the threshold (PECQ of 1.13 and 1.17, respectively) and maxima of Ni were just below (PECQ of 0.95) (Table 3). These results were generally in agreement with $\mathrm{I}_{\text {geo }}$ classification, except for $\mathrm{Cd}$, which showed a moderate enrichment according to Igeo but no risk according to PECQ. Local geochemical background for this metal is not known; therefore, the median shale value considered for $I_{\text {geo }}$ calculation may be misleading. Another hypothesis is that an anthropogenic contribution may derive from atmospheric transport, but in any case concentrations remain below the ecotoxicological threshold. 
Table 1. Range (min, $\max$ ) and median value of parameters descriptive of 20 Subalpine reservoirs considered for sediment analysis. Concentrations of trace elements and organics in sediments (analyzed on $<2 \mathrm{~mm}$ grain size fraction) are reported. Concentrations of organics are normalized to \%TOC. Probable Effect Concentrations $\left(\mathrm{PEC}_{\mathrm{i}}\right)$ are also reported for each contaminant according to MacDonald et al. [41] and Marshall et al. [42]. a.s.l. = above sea level; d.w. = dry weight.

\begin{tabular}{|c|c|c|c|c|c|}
\hline Parameter & Unit & Min & Max & Median & PEC $_{i}$ \\
\hline Altitude & m a.s.l. & 237 & 2987 & 1051 & \\
\hline Sedimentation rate & $\mathrm{cm}_{\text {year }}{ }^{-1}$ & 0.1 & 74.1 & 5.6 & \\
\hline Sedimentation level & $\%$ volume year ${ }^{-1}$ & 0.001 & 8.56 & 0.41 & \\
\hline Volume & $\mathrm{M}^{3} 10^{6}$ & 0.05 & 63 & 0.35 & \\
\hline Surface & $\mathrm{Km}^{2}$ & 0.02 & 2.2 & 0.04 & \\
\hline Max depth & $\mathrm{m}$ & 9 & 86 & 27 & \\
\hline Fine fraction & $\%<2 \mathrm{~mm}$ & 15.3 & 100 & 90.85 & \\
\hline TOC & $\mathrm{g} \mathrm{kg}^{-1}$ d.w. & 0.06 & 108 & 1.3 & \\
\hline As & $\mathrm{mg} \mathrm{kg}^{-1}$ d.w. & 1.0 & 694.7 & 27.9 & 33 \\
\hline $\mathrm{Cd}$ & $\mathrm{mg} \mathrm{kg}^{-1}$ d.w. & 0.03 & 2.00 & 0.22 & 4.98 \\
\hline $\mathrm{Cr}$ & $\mathrm{mg} \mathrm{kg}^{-1}$ d.w. & 6.8 & 65.3 & 21.6 & 111 \\
\hline $\mathrm{Cu}$ & $\mathrm{mg} \mathrm{kg}^{-1}$ d.w. & 1.4 & 91.5 & 25.5 & 149 \\
\hline $\mathrm{Hg}$ & $\mathrm{mg} \mathrm{kg}^{-1}$ d.w. & 0.01 & 1.20 & 0.04 & 1.06 \\
\hline $\mathrm{Ni}$ & $\mathrm{mg} \mathrm{kg}^{-1}$ d.w. & 2.7 & 46.4 & 19.3 & 48.6 \\
\hline $\mathrm{Pb}$ & $\mathrm{mg} \mathrm{kg}^{-1}$ d.w. & 1.0 & 150.2 & 18.1 & 128 \\
\hline $\mathrm{Zn}$ & $\mathrm{mg} \mathrm{kg}^{-1}$ d.w. & 28.3 & 355.9 & 88.2 & 459 \\
\hline$C>12$ & $\mathrm{mg} \mathrm{kg}^{-1}$ d.w. & 0.5 & 173.1 & 15.8 & 860 \\
\hline PAHs & $\mathrm{mg} \mathrm{kg}^{-1}$ d.w. & 0.0002 & 0.60 & 0.02 & 22.8 \\
\hline PCBs & $\mathrm{mg} \mathrm{kg}^{-1}$ d.w. & 0.0001 & 0.057 & 0.002 & 0.676 \\
\hline
\end{tabular}

Regarding organics, values were all below the PECs, showing no expected risk (Table 3). Considering the risk deriving from the mixture of contaminants in sediments, PECQtot showed maximum values $>2$ (Table 3), emphasizing potential toxicity. However, it must be considered that the assessment of sediment quality is challenging due to the complexity of this environmental matrix and to the persistence of many pollutants such as metals and hydrophobic organic chemicals. Moreover, in aquatic sediments and in particular in lakes, sulfides and organic matter, as well as iron and manganese oxy-hydroxides, play a fundamental role as ligands of micropollutants [51], governing their bioavailability. Besides, local chemical and physical conditions hampers bioavailability predictability and thus assessment of sediment toxicity [52].

Table 2. Range ( $\mathrm{min}, \mathrm{max}$ ) and median value of $\mathrm{I}_{\text {geo }}$ calculated for trace elements analyzed in sediments of 20 Subalpine reservoirs. Classification follows Barbieri [39] and is referred to maximum values.

\begin{tabular}{ccccc}
\hline \multirow{2}{*}{ Parameter } & \multicolumn{3}{c}{ Igeo } \\
\cline { 2 - 5 } & Min & Max & Median & Sediment Quality Classification \\
\hline $\mathrm{As}$ & -2.20 & 4.59 & 1.06 & Strongly polluted to extremely polluted \\
$\mathrm{Cd}$ & -3.04 & 2.12 & -0.33 & Moderately polluted to strongly polluted \\
$\mathrm{Cr}$ & -3.88 & -0.48 & -1.91 & Unpolluted \\
$\mathrm{Cu}$ & -4.03 & -0.31 & -1.28 & Unpolluted \\
$\mathrm{Hg}$ & -4.06 & 1.34 & -2.27 & Moderately polluted \\
$\mathrm{Ni}$ & -4.00 & -0.80 & -1.97 & Unpolluted \\
$\mathrm{Pb}$ & -3.40 & 1.61 & -0.82 & Moderately polluted \\
$\mathrm{Zn}$ & -2.78 & 0.81 & -0.69 & Unpolluted to moderately polluted \\
\hline
\end{tabular}


Table 3. Range (min, max) and median value of PECQ calculated for trace elements and organics

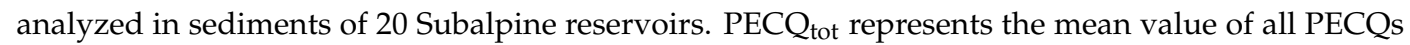
available for each sample.

\begin{tabular}{cccc}
\hline \multirow{2}{*}{ Parameter } & \multicolumn{3}{c}{ PECQs } \\
\cline { 2 - 4 } & Min & Max & Median \\
\hline $\mathrm{As}$ & 0.030 & 21.05 & 0.84 \\
$\mathrm{Cd}$ & 0.005 & 0.40 & 0.04 \\
$\mathrm{Cr}$ & 0.000 & 0.59 & 0.19 \\
$\mathrm{Cu}$ & 0.000 & 0.61 & 0.17 \\
$\mathrm{Hg}$ & 0.009 & 1.13 & 0.03 \\
$\mathrm{Ni}$ & 0.056 & 0.95 & 0.40 \\
$\mathrm{~Pb}$ & 0.008 & 1.17 & 0.14 \\
$\mathrm{Zn}$ & 0.062 & 0.78 & 0.19 \\
$\mathrm{C}>12$ & 0.001 & 0.20 & 0.02 \\
$\mathrm{PAHs}$ & 0.000 & 0.03 & 0.001 \\
PCBs & 0.000 & 0.08 & 0.003 \\
PECQ & 0.000 & 2.25 & 0.22 \\
\hline
\end{tabular}

\subsection{Relations between Sediment Quality and Physical-Chemical Drivers}

To analyze the behavior of different micropollutants in reservoir sediments and to find relationships between pollutant concentrations and physical-chemical variables, two separate PCA analyses were carried out considering trace elements and organics, respectively.

The first PCA included trace element concentrations and allowed to group metals according to different behaviors (Figure 3a).

As and $\mathrm{Zn}$ were grouped along the first PCA axis, which accounted for $44 \%$ of total variance. These elements were inversely related to volume and lake surface and were orthogonal (i.e., not related) to sedimentation, altitude and TOC. The behavior of these two chalcophilic elements can be attributed to similar mechanisms controlling weathering by adsorption on clay, $\mathrm{Fe}, \mathrm{Mn}$ and $\mathrm{Al}$ oxy-hydroxides and organic matter [53,54]. Localized mineralization typical in the Alps, with the presence of a variety of sulfide and sulfarsenide minerals, notably arsenopyrite [55-57], may be responsible of the high concentrations of As found in some reservoirs, in particular in the small ones. This confirms that the high values of $\mathrm{I}_{\text {geo }}$ obtained for this element can be largely ascribed to natural factors.

The second PCA axis accounted for $26 \%$ of total variance, and was negatively correlated to $\mathrm{Pb}$, $\mathrm{Cd}$ and $\mathrm{Hg}$ (Figure 3a). These elements are strongly linked to atmospheric deposition [58-61] and they are generally bond onto suspended particle in the water column. In fact, the direct relation to fine sediments $(<2 \mathrm{~mm})$ and TOC indicates that ligands can influence their distribution. The inverse relation to depth confirms that their fate is largely conditioned by the presence of natural simple or complex ligands (like fulvic and humic compounds) and colloidal particles [62-64].

$\mathrm{Cu}, \mathrm{Cr}$ and $\mathrm{Ni}$ were positively correlated to the second PCA axis and were negatively related to altitude and to a lesser extent to sediment fine fraction (Figure 3a). The higher concentrations found in reservoirs placed at lower altitude could be linked to increased anthropogenic pressure [53], or to natural increase of concentrations due to weathering processes $[65,66]$. $\mathrm{Cu}$ and $\mathrm{Ni}$ are generally bond to natural ligands both in the water column and in sediments [67-71]. In addition, $\mathrm{Cr}$ under near-neutral $\mathrm{pH}$ can be considered a low mobility element bond to organic ligands and clays, which stabilize the element in the sediment matrix [72].

The second PCA analysis was carried out considering concentrations of organics as variables (Figure $3 \mathrm{~b}$ ). The first axis account for $51 \%$ of total variance and was positively correlated to PAHs and $C>12$. These compounds showed an inverse relation to depth, volume and surface area. Their concentrations in sediments were higher in small and shallow lakes, as confirmed by the positive relation to sedimentation. They showed no relation to altitude and fine sediment fraction $(<2 \mathrm{~mm})$. 
The second PCA axis accounted for $30 \%$ of total variance, and was positively correlated to PCB concentrations (Figure 3b). In our case study, PCBs seem to be linked with sources localized at low altitude, as showed by the inverse relation to altitude.

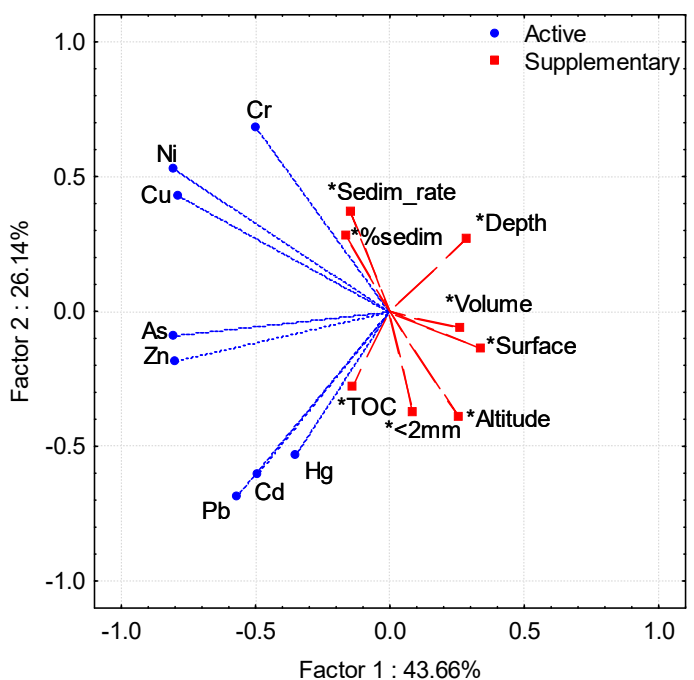

(a)

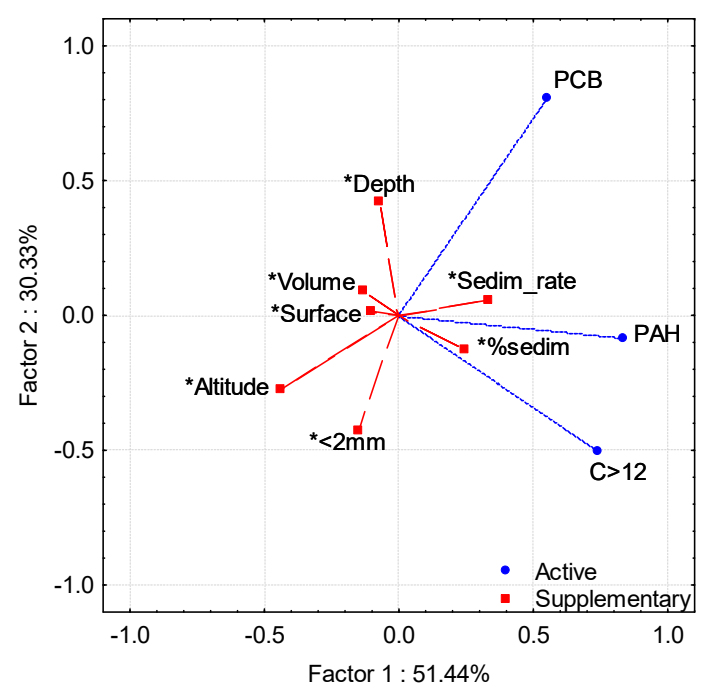

(b)

Figure 3. Plots of Principal Component Analysis according to axis 1 and 2 of: (a) trace elements; and (b) organics. Active and supplementary variables are represented. Sedim_rate $=$ sedimentation rate; \%sedim = sedimentation level.

The PCA analyses also allowed finding relationships between physical-chemical characters of sediments (fine fraction $<2 \mathrm{~mm}$, TOC, sedimentation rate and percent sedimentation) and morphometric features of reservoirs (altitude, surface area, maximum depth and volume) (Figure 3). Sedimentation rate and percent sedimentation decreased with altitude and were slightly related to morphometric features of reservoirs. These variables are generally related to lithological and morphological characteristics of catchments [37,73-75]. Increasing sedimentation with diminishing altitude can be linked to increasing fluxes of coarse particulate in sediments at low altitudes. Fine particulate sediments rich in organic matter, typical of natural catchments, are instead more abundant at high elevations $[74,76,77]$. In fact, TOC and fine sediment fraction $(<2 \mathrm{~mm})$ were strongly related, meaning that organic matter is mainly associated to this fraction [74,77-79]. Both were positively related to altitude and inversely to sedimentation rate and percent sedimentation. Grain size is one of main physical characteristics determining the accumulation of micropollutants in sediments $[3,37,79-81]$. In addition, TOC plays a fundamental role in the retention of contaminants in sediments $[3,16,51,82-84]$. Therefore, the inverse relation between some micropollutant concentrations (e.g., $\mathrm{Cd}, \mathrm{Pb}$ and $\mathrm{Hg}$ ) and sedimentation highlighted in the PCA analyses can be explained considering the dilution factor determined by increasing coarse sediments at lower altitudes. Increasing concentrations of some pollutants $(\mathrm{Cu}, \mathrm{Ni}, \mathrm{Cr}$ and organics) at higher sedimentation rate may be related to different land-use (i.e., more anthropogenic sources at lower altitudes) or to increased weathering.

The PCA analyses allowed confirming sedimentation, granulometry, TOC and land-use as the main drivers determining the distribution of contaminants in reservoirs. All these variables are strongly influenced by climate change; therefore, it is possible to infer how climate change will affect these drivers and, in turns, how these changes may affect the concentrations of the analyzed pollutants [85].

\subsection{Potential Effects of Climate Change on Sediment Quality in Reservoirs}

The erosive power of rainfall can be expected to change with increase of precipitation intensity $[13,43,86,87]$. Consequently, the increased erosion rates can elevate the sediment delivery 
from catchments [88] and lakes and reservoirs act as primary sink in the sediment cascade [89]. Increases of sedimentation rate have been observed in many European lakes over the last 100 years, in particular during 1950-1975 and post-1975. This indicates a general acceleration in sedimentation rate during the second half of the twentieth century [90]. Whereas increases in sedimentation rate in many lowland areas may be due to changes in agricultural practices and other land-use changes in the lake catchments, the same cannot be said of upland and mountain lakes where land-use has remained largely unchanged. Some authors (e.g., [91,92]) explained these sedimentation rate increases as a consequence of climate change. Moreover, in upland lakes predicted increases in air and water temperatures could result in shorter periods of ice-cover and thus the rate of mineralization of organic matter in catchment soils is expected to be enhanced, releasing both carbon and nitrogen $[93,94]$. In fact, TOC is also considered as a proxy of variability of lacustrine sediments related to climate change $[95,96]$. Furthermore, higher winter rainfall, prolonged periods of summer drought and increased frequency of extreme events could enhance catchment soil erosion resulting in an increased amount of allochthonous material reaching lake sediments [97].

Another important consequence expected in the Alps is the altitudinal shift of climatic zones in the Alpine area [98], with variations of vegetation cover expected mainly as tree line rise $[99,100]$. Both rainfall erosivity and vegetation cover changes are among the most important dynamic factors in developing modeling scenarios of soil erosion [43,101,102].

To infer potential consequences of climate change on sediment quality in our case studies, the models by Panagos et al. [13] for rainfall erosivity and the models by Rubel et al. [10] for climate classification were considered.

Figure 4a shows the predicted changes in rainfall erosivity for 2050 scenario [13]. Generally, the Alpine area is characterized by moderate (from 0 to $50 \mathrm{MJ} \mathrm{mm} \mathrm{ha}{ }^{-1} \mathrm{~h}^{-1}$ year ${ }^{-1}$ ) to high (from 300 to $500 \mathrm{MJ} \mathrm{mm} \mathrm{ha}^{-1} \mathrm{~h}^{-1}$ year $^{-1}$ ) increase of rainfall erosivity (R-factor), as well as our region of investigation, although slightly lower than in the northern slope of the Alpine chain (Switzerland). The forecasted increase of the R-factor is mainly due to a predicted increase of rainfall intensity in the next decades in the entire Alpine chain. The same trend has been observed even in recent past decades in Northern Italy [29]. That means an enhancement of processes associated with soil erosion and, consequently, an increase of sediment flux [103]. It can be supposed that the greater energy expressed by increased rainfall erosivity, coupled with the contribution of the reduction of permafrost in high elevation [104], will lead to higher rates of coarse materials, with a relative decrease of fine sediment fractions.

Considering models for climate classification, a visual interpolation of the moderate and extremes scenarios (Figure $4 \mathrm{~b}-\mathrm{d}$ ) indicates that during the second half of this century (2076-2100) we can expect an important increase of the area classified as "warm temperate", a sharp decrease of the area classified as "alpine" and an important decrease of the area classified as "boreal" [10]. That means that the vegetation cover is expected to increase with altitude, with a significant rise of the tree line.

Based on the above considerations, hypotheses on the effect of climate change in the second half of this century on quality of sediments in reservoirs can be formulated (Table 4). In general, an increase of sediments flow (i.e., sedimentation rate and sedimentation level) can be predicted, potentially with increased coarse grain fractions than observed at present (i.e., decreased fine sediment fraction $<2 \mathrm{~mm}$ ). Basing on these hypotheses, the increased rate of coarse sediments may result in a greater dilution of contaminants, which may show lower concentrations than in the present scenario. Nevertheless, the changing of the extent of mechanisms governing weathering, release and transport of natural contaminants from the catchment, for example permafrost reduction [104], will potentially counteract with increased metal fluxes to the aquatic environment. Therefore, it is hardly predictable how these contrasting mechanisms will affect contaminant concentrations: anthropogenic pollutants may potentially be diluted by increased coarse material fractions [3], but concentrations of trace elements deriving from natural erosion may increase [105]. On the other hand, the increased forest and plant coverage [106] will result in higher capacity of soils to storage organic material and the 
degradation of litter and vegetation will potentially increase the flow of TOC to reservoirs $[77,107,108]$. This will potentially reduce bioavailability of pollutants due to the enhanced presence of ligands, with resulting reduced toxicity risk for aquatic organisms.

a)

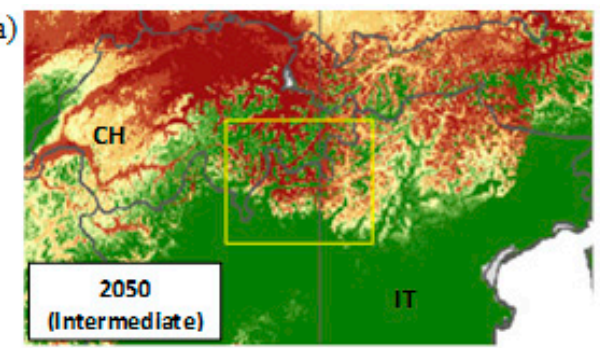

b)

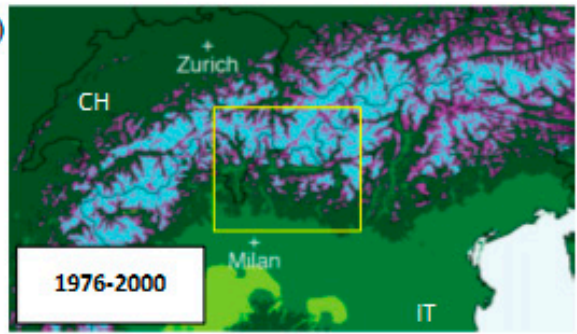

c)

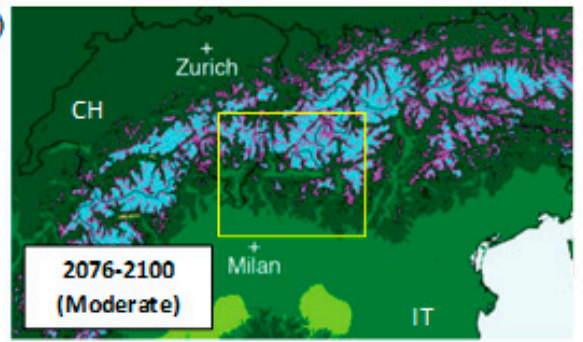

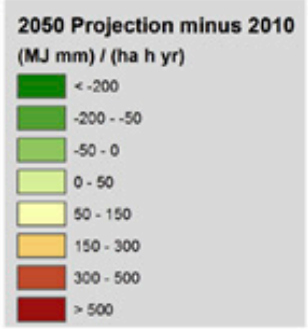

arid

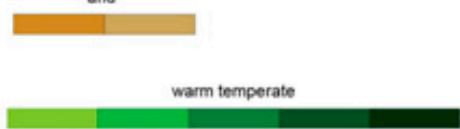

boreal

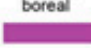

alpine

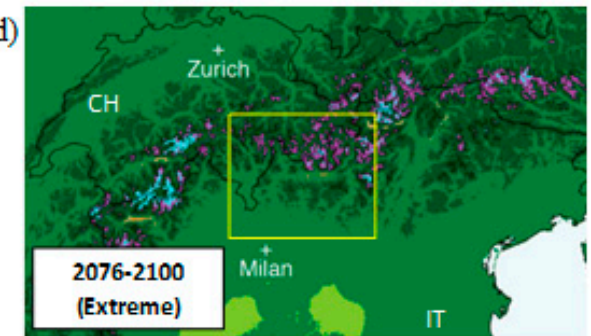

Figure 4. (a) Projection of rainfall erosivity in the study area (yellow square): map modified from Panagos et al. [43], representing the absolute difference of R-factor between 2050 projections and 2010 data. (b-d) Maps of Köppen-Geiger climate classification calculated from projected temperature and precipitation data (modified from Rubel et al. [10]): (b) present period (1976-2000) vs. projections for period 2076-2100 according to: (c) moderate (RCP2.6) case scenario; and (d) extreme (RCP8.5) case scenario.

Table 4. Scenarios on possible effects of climate change on drivers affecting contaminant concentrations in reservoir sediments and, thus, on sediment contamination.

\begin{tabular}{lcl}
\hline Drivers & Effects of Climate Change & Effect on Sediment Contamination \\
\hline Runoff & $\begin{array}{c}\text { Increased flux of sediments and coarse } \\
\text { materials into the reservoirs }\end{array}$ & Pollutant dilution \\
\hline Siltation rate & $\begin{array}{c}\text { Increased flux of allochthonous material into } \\
\text { the reservoirs }\end{array}$ & Pollutant dilution \\
\hline Permafrost & $\begin{array}{c}\text { Increased fluxes of trace elements and organic } \\
\text { matter into the reservoirs }\end{array}$ & Increased metal and TOC concentrations \\
\hline Tree line & $\begin{array}{c}\text { Increased fluxes of organic matter into } \\
\text { the reservoirs }\end{array}$ & Increased TOC concentrations \\
\hline TOC & $\begin{array}{c}\text { Increased availability of organic ligands in } \\
\text { sediments and water column }\end{array}$ & Reduced bioavailability of pollutants \\
\hline
\end{tabular}




\subsection{Management Directions}

In a climate change scenario, reservoirs play a crucial role as water storage, both for energy production and for irrigation use or drinking water supply. For this reason, stakeholders need to cope with the reduction of storage capacity due to siltation and have to find solutions for a sustainable management of reservoir sediments in accordance with Water Framework Directive (2000/60/EC), with the aim of preserving both water quality and aquatic ecosystem functioning $[15,16]$. Our analysis shows that sediment quality in reservoirs is a key issue to be addressed, since they act as a sink for micropollutants, preventing their transport downstream. However, management operations such as flushing, sluicing, dredging or hydropeaking may cause a release of contaminants into the water column $[3,14]$, thus impairing water quality and aquatic communities. Furthermore, climate change may affect important drivers governing the fate of pollutants accumulated into sediments.

In Northern Italy, a protocol for assessing the toxicity risk of reservoir sediments was developed in order to plan proper flushing operations [16]. The protocol includes standard methods for sampling, chemical analysis, ecotoxicological and ecological characterization of sediments of the reservoirs and of the downstream river stretches. It also includes criteria for risk assessment using an approach similar to TRIAD (e.g., [52]), which takes into account: (1) the comparison of micropollutant concentrations in sediments with ecotoxicological thresholds selected from existing national legislation or from literature (e.g., PECs [41]); (2) the assessment of sediment toxicity using ecotoxicological test batteries (comprising tests both on whole-sediments and leachates); and (3) the assessment of aquatic communities in the downstream river stretches according to official monitoring protocols. Results of chemical, ecotoxicological and ecological assessment before flushing is considered as basis for planning proper operations, and after flushing as criteria to evaluate the results of the operations by comparison with the previous conditions. The final aim of the characterization is to provide practical information for a sustainable management of flushing operations. As a key output of the application of this protocol, a proper sediment:water dilution factor to be applied during flushing can be derived for each case study to prevent exceedance of toxicity thresholds.

In this framework, assessing potential effects of climate change on sediment quality in reservoirs can provide important management indications. In our analysis, three major drivers affecting sediment quality were identified: sedimentation, granulometry and TOC. As regard sedimentation, increased sedimentation rates are expected, thus higher volumes of sediments will need to be removed from reservoirs. It can be supposed that more frequent flushing operations will be carried out, determining stronger physical impacts on the downstream aquatic communities (e.g., [14,109]). As regard granulometry, coarser sediments are expected to accumulate into reservoirs, thus potentially diluting contaminant concentrations; on the other hand, stronger weathering, soil erosion and permafrost reduction may increase trace element fluxes into reservoirs, increasing concentrations in sediments. Therefore, two opposite hypotheses can be formulated. If pollutant concentrations will be reduced, then the sediment:water dilution factor to be applied during flushing to prevent toxicity could be increased, thus making management easier. On the contrary, with increased trace metal concentrations stronger dilution of sediments in water during operations will need to be applied, increasing logistical problems: flushing operations will be potentially carried out only during high flow conditions. Moreover, Frémion et al. [16] showed that the solid/liquid ratio is one of the main factors determining the release of trace metals from sediments: the lower the ratio the higher the release. Therefore, a higher sediment:water dilution factor may result in enhanced metal release in the dissolved phase. Counteracting this, TOC concentrations in sediments may increase due to increased erosion of vegetated sediment soils: this will also potentially contribute to dilute pollutant concentrations (e.g., [3]). Besides, the increased presence of organic ligands may prevent pollutant release into the water column during flushing and/or increase complexation of contaminants present in the dissolved phase, thus potentially reducing bioavailability and, in turns, toxicity. 


\section{Conclusions}

Our analysis allowed identifying the main drivers affecting contaminant concentrations in reservoir sediments. These results were used to infer potential effects of climate change on sediment quality. Only changes in the catchment area were considered, omitting those that could occur in the water body, such as changing in thermal stratification, increased anoxia and consequent release of nutrients or pollutants, changing in nutrients loads and consequences on water quality. These are considered minor issues in Northern Italian reservoirs since water regulation for hydropower generally determines short (e.g., daily) water residence times. In addition, in this scenario, we did not consider any variations of potential sources of anthropogenic pollution. Potential effects of climate change on sediment contamination and consequences on management followed a speculative approach, and thus results should be interpreted with caution. However, sedimentation, granulometry and organic matter were confirmed as key factors governing contaminant concentrations in sediments. Therefore, monitoring dynamics of these drivers may give crucial elements for a proper management of reservoir siltation in a climate change scenario.

Acknowledgments: This research was partially funded by Italian Lombardy Region and Lombardy Regional Environmental Protection Agency (ARPA Lombardia) within the projects "Dams 2012-2013: Technical-scientific support for water uses, dam safety and reservoir management" and "Dams 2014-2016: Validation of the protocol for the ecotoxicological and chemical characterization of reservoir sediments".

Author Contributions: L.M. and G.T. conceived and designed the study and wrote the paper; L.M. and L.V. performed data analysis; F.S. and L.G. provided important advice on the concept of the methodology and the writing of the manuscript; and C.B., E.L. and P.G. provided the dataset.

Conflicts of Interest: The authors declare no conflict of interest.

\section{References}

1. Syvitski, J.P.M.; Kettner, A. Sediment flux and anthropocene. Phil. Trans. R. Soc. A 2011, 369, 957-975. [CrossRef] [PubMed]

2. Brooks, B.W.; Lazorchak, J.M.; Howard, M.D.A.; Johnson, M.-V.V.; Morton, S.L.; Perkins, D.A.K.; Reavie, E.D.; Scott, G.I.; Smith, S.A.; Steevens, J.A. Are harmful algal blooms becoming the greatest inland water quality threat to public health and aquatic ecosystems? Environ. Toxicol. Chem. 2016, 35, 6-13. [CrossRef] [PubMed]

3. Frémion, F.; Courtin-Nomade, A.; Bordas, F.; Lenain, J.-F.; Jugé, P.; Kestens, T.; Mourier, B. Impact of sediments resuspension on metal solubilization and water quality during recurrent reservoir sluicing management. Sci. Total. Environ. 2016, 562, 201-215. [CrossRef] [PubMed]

4. Su, F.; Kaplan, D.; Li, L.; Li, H.; Song, F.; Liu, H. Identifying and classifying pollution hotspots to guide watershed management in a large multiuse watershed. Int. J. Environ. Res. Public Health 2016, 14, 260. [CrossRef] [PubMed]

5. Annadale, G.W. Sedimentation and climate change: Managing global threats to water supply reliability and sustainability. In Proceedings of the ICSE6 Paris, Paris, France, 27-31 August 2012; pp. 1185-1192.

6. Mei, Y.; Chang, C.-C.; Dong, Z.; Wei, L. Stream; Lake; and Reservoir Management. Water Environ. Res. 2016, 88, 1533-1563. [CrossRef] [PubMed]

7. Schleiss, A.J.; Franza, M.J.; Juez, C.; De Cesare, G. Reservoir sedimentation. J. Hydraul. Res. 2016, 54, 595-614. [CrossRef]

8. Alighalehbabakhani, F.; Miller, C.J.; Selegean, J.P.; Barkech, J.; Sadatiyan Abkenar, S.M.; Dahl, T.; Baskaran, M. Estimates of sediment trapping rates for two reservoirs in the Lake Erie watershed: Past and present scenarios. J. Hydrol. 2017, 544, 147-155. [CrossRef]

9. Chen, F.X.; Fang, N.F.; Wang, Y.X.; Tong, L.S.; Shi, Z.H. Biomarkers in sedimentary sequences: Indicators to track sediment sources over decadal timescales. Geomorphology 2017, 278, 1-11. [CrossRef]

10. Rubel, F.; Brugger, K.; Haslinger, K.; Auer, I. The climate of the European Alps: Shift of very high resolution Köppen-Geiger climate zones 1800-2100. Meteorol. Z. 2016, 26, 115-125. [CrossRef]

11. Kondolf, G.M.; Gao, Y.; Annadale, G.W.; Morris, G.L.; Jiang, E.; Zhang, J.; Cao, Y.; Carling, P.; Fu, K.; Guo, Q.; et al. Sustainable sediment management in reservoirs and regulated rivers: Experiences from five continents. Earth's Future 2014, 2, 256-280. [CrossRef] 
12. Yasarer, L.M.W.; Sturm, B.S.M. Potential impacts of climate change on reservoir services and management approaches. Lake Reserv. Manag. 2016, 32, 13-26. [CrossRef]

13. Panagos, P.; Borrelli, P.; Meusburger, K.; Yu, B.; Klik, A.; Lim, K.J.; Yang, J.E.; Ni, J.; Miao, C.; Chattopadhyay, N.; et al. Global rainfall erosivity assessment based on high-temporal resolution rainfall record. Sci. Rep. 2017, 7, 4175. [CrossRef] [PubMed]

14. Hug Peter, D.; Castella, E.; Slaveykova, V.I. Effects of a reservoir flushing on trace metal partitioning; speciation and benthic invertebrates in the floodplain. Environ. Sci. Process. Impacts 2014, 16, 2692-2702. [CrossRef] [PubMed]

15. Marziali, L.; Guzzella, L.; Tartari, G.; Valsecchi, L.; Genoni, P.; Lorenzi, E.; Bravi, C. A protocol for assessing sediment toxicity in reservoirs of Lombardy Region (Northern Italy) before flushing. Biol. Ambient. 2017, 31, 1-7.

16. Frémion, F.; Bordas, F.; Mourier, B.; Lenain, J.-F.; Kestens, T.; Courtin-Nomade, A. Influence of dams on sediment continuity: A study case of a natural metallic contamination. Sci. Total Environ. 2016, 547, 282-294. [CrossRef] [PubMed]

17. Adrian, R.; O’Reilly, C.M.; Zagarese, H.; Baines, S.B.; Hessen, D.O.; Keller, W.; Livingstone, D.M.; Sommaruga, R.; Straile, D.; van Donk, E.; et al. Lakes as sentinels of climate change. Limnol. Oceanogr. 2009, 54, 2283-2297. [CrossRef] [PubMed]

18. Hayes, N.M.; Deemer, B.R.; Corman, J.R.; Razavi, R.; Strock, K.E. Key differences between lakes and reservoirs modify climate signals: A case for a new conceptual model. Limnol. Oceanogr. Lett. 2017, 2, 47-62. [CrossRef]

19. Rosenzweig, C.; Casassa, G.; Karoly, D.J.; Imeson, A.; Liu, C.; Menzel, A.; Rawlins, S.; Root, T.L.; Seguin, B.; Tryjanowski, P. Assessment of observed changes and responses in natural and managed systems. In Climate Change 2007: Impacts; Adaptation and Vulnerability; Contribution of Working Group II to the Fourth Assessment Report of the Intergovernmental Panel on Climate Change; Parry, M.L., Canziani, O.F., Palutikof, J.P., van der Linden, P.J., Hanson, C.E., Eds.; Cambridge University Press: Cambridge, UK, 2007; pp. 79-131, ISBN 9780521 88010-7.

20. Pham, S.V.; Leavitt, P.R.; McGowan, S.; Peres-Nato, P. Spatial variability of climate and land-use effects on lakes of the northern Great Plains. Limnol. Oceanogr. 2008, 53, 728-742. [CrossRef]

21. Williamson, C.E.; Dodds, W.; Kratz, T.K.; Palmer, M.A. Lakes and streams as sentinels of environmental change in terrestrial and atmospheric processes. Front. Ecol. Environ. 2008, 6, 247-254. [CrossRef]

22. Salerno, F.; Gambelli, S.; Viviano, G.; Thakuri, S.; Guyennon, N.; D’Agata, C.; Diolaiuti, G.; Smiraglia, C.; Stefani, F.; Bocchiola, D.; et al. High alpine ponds shift upwards as average temperature increase: A case study of the Ortles-Cevedale mountain group (Southern Alps; Italy) over the last 50 years. Glob. Planet. Chang. 2014, 120, 81-91. [CrossRef]

23. Auer, I.; Böhm, R.; Jurkovic, A.; Lipa, W.; Orlik, A.; Potzman, R.; Schöner, W.; Ungersböck, M.; Matulla, C.; Briffa, K.; et al. HISTALP-Historical instrumental climatological surface time series of the Greater Alpine Region. Int. J. Climatol. 2007, 27, 17-46. [CrossRef]

24. Ciccarelli, N.; von Hardenberg, J.; Provenzale, A.; Ronchi, C.; Vargiu, A.; Pelosini, R. Climate variability in north-western Italy during the second half of the 20th century. Glob. Planet. Chang. 2008, 63, 185-195. [CrossRef]

25. Brunetti, M.; Maugeri, M.; Monti, F.; Nanni, T. Changes in daily precipitation frequency and distribution in Italy over the last 120 years. J. Geophys. Res. 2004, 109. [CrossRef]

26. Brunetti, M.; Maugeri, M.; Monti, F.; Nanni, T. Temperature and precipitation variability in Italy in the last two centuries from homogenised instrumental time series. Int. J. Climatol. 2006, 26, 345-381. [CrossRef]

27. Brunetti, M.; Lentini, G.; Maugeri, M.; Nanni, T.; Auer, I.; Böhm, R.; Schöner, W. Climate variability and change in the Greater Alpine Region over the last two centuries based on multi-variable analysis. Int. J. Climatol. 2009, 29, 2197-2225. [CrossRef]

28. Brugnara, Y.; Brunetti, M.; Maugeri, M.; Nanni, T.; Simolo, C. High-resolution analysis of daily precipitation trends in the central Alps over the last century. Int. J. Climatol. 2012, 32, 1406-1422. [CrossRef]

29. Brunetti, M.; Buffoni, L.; Maugeri, M.; Nanni, T. Precipitation intensity trends in northern Italy. Int. J. Climatol. 2000, 20, 1017-1031. [CrossRef]

30. Inter-Governmental Panel on Climate Change (IPCC). Climate Change 2014: Synthesis Report. In Contribution of Working Groups I; II and III to the Fifth Assessment Report of the Intergovernmental Panel on Climate Change; Pachauri, R.K., Meyer, L.A., Eds.; IPCC: Geneva, The Switzerland, 2014; p. 151, ISBN 978-92-9169-143-2. 
31. Doglioni, C.; Flores, G. An Introduction to the Italian Geology; Lamisco: Potenza, Italy, 1997; p. 98.

32. Costantini, E.A.C.; Barbetti, R.; Fantappiè, M.; L'Abate, G.; Lorenzetti, R.; Magini, S. Pedodiversity. In The Soils of Italy; World Soils Book Series; Costantini, E.A.C., Dazzi, C., Eds.; Springer Science+Business Media: Dordrecht, The Netherlands, 2013; pp. 105-178. [CrossRef]

33. Costantini, E.A.C.; Fantappiè, M.; L'Abate, G. Climate and Pedoclimate of Italy. In The Soils of Italy; Costantini, E.A.C., Dazzi, C., Eds.; World Soils Book Series; Springer Science+Business Media: Dordrecht, The Netherlands, 2013; pp. 19-38. [CrossRef]

34. Belda, M.; Holtanová, E.; Halenka, T.; Kalvová, J. Climate classification revisited from Köppen to Trewartha. Clim. Res. 2014, 59, 1-13. [CrossRef]

35. Tartari, G.; Buraschi, E.; Monguzzi, C.; Marchetto, A.; Copetti, D.; Previtali, L.; Salerno, F.; Tatti, S.; Barbiero, G.; Pagnotta, R. Progetto LIMNO: Qualità delle acque lacustri italiane. In Quaderni IRSA; Istituto di Ricerca Sulle Acque, Consiglio Nazionale delle Ricerche: Roma, Italy, 2003; Volume 339, ISSN 0390-6329.

36. Buraschi, E.; Salerno, F.; Monguzzi, C.; Barbiero, G.; Tartari, G. Characterization of the Italian lake-types and identification of their reference sites using anthropogenic pressure factors. J. Limnol. 2005, 64, 75-84. [CrossRef]

37. Håkanson, L. Models to predict net and gross sedimentation in lakes. Mar. Freshw. Res. 1995, 46, 305-319.

38. Müller, G. Die Schwermetallbelastung der Sedimente des Neckars und seiner Nebenflusse: Eine Bestandsaufnahme. Chem. Zeit. 1981, 105, 157-164.

39. Barbieri, M. The Importance of Enrichment Factor (EF) and Geoaccumulation Index $\left(\mathrm{I}_{\mathrm{geo}}\right)$ to Evaluate the Soil Contamination. J. Geol. Geophys. 2016, 5, 237. [CrossRef]

40. Long, E.R.; Ingersoll, C.G.; MacDonald, D.D. Calculation and Uses of Mean Sediment Quality Guideline Quotients: A Critical Review. Environ. Sci. Technol. 2006, 40, 1726-1736. [CrossRef] [PubMed]

41. MacDonald, D.D.; Ingersoll, C.G.; Berger, T.A. Development and evaluation of consensus-based sediment quality guidelines for freshwater ecosystems. Arch. Environ. Contam. Toxicol. 2000, 39, 20-31. [CrossRef] [PubMed]

42. Marshall, S.; Pettigrove, V.; Carewa, M.; Hoffmann, A. Isolating the impact of sediment toxicity in urban streams. Environ. Poll. 2010, 158, 1716-1725. [CrossRef] [PubMed]

43. Panagos, P.; Ballabio, C.; Meusburger, K.; Spinono, J.; Alewell, C.; Borrelli, P. Towards estimates of future rainfall erosivity in Europe based on REDES and WorldClim datasets. J. Hydrol. 2017, 548, 251-262. [CrossRef] [PubMed]

44. Jones, C.G.; Samuelsson, P.; Kjellström, E. Regional climate modelling at the Rossby Centre. Tellus 2011, 63, 1-3. [CrossRef]

45. Grimalt, J.O.; van Droogea, B.L.; Ribesa, A.; Fernández, P.; Appleby, P. Polycyclic aromatic hydrocarbon composition in soils and sediments of high altitude lakes. Environ. Pollut. 2004, 131, 13-24. [CrossRef] [PubMed]

46. El-Shahawi, M.-S.; Hamza, A.; Bashammakh, A.S.; Al-Saggaf, W.T. An overview on the accumulation, distribution, transformations, toxicity and analytical methods for the monitoring of persistent organic pollutants. Talanta 2010, 80, 1587-1597. [CrossRef] [PubMed]

47. Stogiannidis, E.; Laane, R. Source characterization of polycyclic aromatic hydrocarbons by using their molecular indices: An overview of possibilities. Rev. Environ. Contam. Toxicol. 2015, 234, 49-133. [CrossRef] [PubMed]

48. Gao, X.; Chena, S.; Xie, X.; Ma, F. Non-aromatic hydrocarbons in surface sediments near the Pearl River estuary in the South China Sea. Environ. Pollut. 2007, 148, 40-47. [CrossRef] [PubMed]

49. Scholz-Böttcher, B.M.; Ahlf, S.; Vázquez-Gutiérrez, F.; Rullkötter, J. Natural vs. anthropogenic sources of hydrocarbons as revealed through biomarker analysis: A case study in the southern Gulf of Mexico. Bol. Soc. Geol. Mex. 2009, 61, 47-56.

50. Dos Santos, M.M.; de Almeida Brehm, F.; Filippe, T.C.; Reicert, G.; de Azwvedo, J.C.R. PAHs diagnostic ratios for the distinction of petrogenic and pirogenic sources: Applicability in the Upper Iguassu Watershed-Parana; Brazil. RBRH 2017, 22, e9. [CrossRef]

51. Landner, L.; Reuther, R. Speciation; mobility and bioavailability of metals in the environment. Environ. Pollut. 2005, 8, 139-274. 
52. Marziali, L.; Rosignoli, F.; Drago, A.; Pascariello, S.; Valsecchi, L.; Rossaro, B.; Guzzella, L. Toxicity risk assessment of mercury; DDT and arsenic legacy pollution in sediments: A triad approach under low concentration conditions. Sci. Total Environ. 2017, 593, 809-821. [CrossRef] [PubMed]

53. Marshall, C.P.; Fairbridge, R.W. (Eds.) Encyclopedia of Geochemistry; Kluwer Academic Publishers: Dordrecht, The Netherlands, 1999; p. 712, ISBN 978-1-4020-5111-1.

54. Swedlung, P.J.; Webster, J.G. Asdorption and polymerization of silicic acid on ferrihydrite; and its effects on arsenic adsorption. Water Res. 1999, 33, 3413-3422. [CrossRef]

55. Petrini, R.; Slejko, F.; Lutman, A.; Pison, S.; Franceschini, G.; Zini, L.; Galic, A. Natural arsenic contamination in waters from the Pesariis village; NE Italy. Environ. Earth Sci. 2011, 62, 481-491. [CrossRef]

56. Tisserand, D.; Pili, E.; Hellmann, R.; Boullier, A.-M.; Charlet, L. Geogenic arsenic in groundwaters in the western Alps. J. Hydrol. 2014, 518, 317-325. [CrossRef]

57. Peña Reyes, F.A.; Crosta, G.B.; Frattini, P.; Basiricò, S.; Della Pergola, R. Hydrogeochemical overview and natural arsenic occurrence in groundwater from alpine springs (upper Valtellina; Northern Italy). J. Hydrol. 2015, 529, 1530-1549. [CrossRef]

58. Turner, D.R. Speciation and cycling of arsenic; cadmium; lead and mercury in natural waters. In Lead; Mercury; Cadmium and Arsenic in the Environment; Hutchinson, T.C., Meema, K.M., Eds.; SCOPE, John Wiley \& Sons Ltd.: Chichester, UK, 1987; Chapter 12; pp. 175-186.

59. Fitzgerald, W.F.; Engstrom, D.R.; Mason, R.P.; Nater, E.A. The Case for Atmospheric Mercury Contamination in Remote Areas. Environ. Sci. Technol. 1998, 32, 1-7. [CrossRef]

60. Norton, S.A.; Dillon, P.J.; Evans, R.D.; Mierle, G.; Kal, J.S. The history of atmospheric deposition of Cd; $\mathrm{Hg}$ and $\mathrm{Pb}$ in North America: Evidence from lake and peat bog sediments. In Acidic Precipitation: Sources; Deposition; and Canopy Interactions; Lindberg, S.E., Page, A.L., Norton, S.A., Eds.; Springer: New York, NY, USA, 1990; pp. 73-102, ISBN 978-1-4612-4454-7.

61. Norton, S.A. Atmospheric Metal Pollutants-Archives; Methods; and History. Water Air Soil Pollut. Focus 2007, 7, 93-98. [CrossRef]

62. Fisher, E.F.; van den Berg, C.M.G. Determination of lead complexation in lake water by cathodic stripping voltammetry and ligand competition. Anal. Chim. Acta 2001, 432, 11-20. [CrossRef]

63. Buffle, J.; Zhang, Z.; Startchev, K. Metal Flux and Dynamic Speciation at (Bio)interfaces. Part I: Critical Evaluation and Compilation of Physicochemical Parameters for Complexes with Simple Ligands and Fulvic/Humic Substances. Environ. Sci. Technol. 2007, 41, 7609-7620. [CrossRef] [PubMed]

64. Riccardi, D.; Guo, H.B.; Park, J.M.; Gu, B.; Summers, A.O.; Miller, S.M.; Liang, L.; Smith, J.C. Why Mercury Prefers Soft Ligands. J. Phys. Chem. Lett. 2013, 4, 2317-2322. [CrossRef]

65. White, A.F.; Blum, E.B. Effects of climate on chemical weathering in watersheds. Geochim. Cosmochim. Acta 1995, 59, 1729-1747. [CrossRef]

66. Fitzsimons, S.J.; Veit, H. Geology and Geomorphology of the European Alps and the Southern Alps of New Zealand. Mt. Res. Dev. 2001, 21, 340-349. [CrossRef]

67. Xue, H.B.; Kistler, D.; Sigg, L. Competition of copper and zinc for strong ligands in a eutrophic lake. Limnol. Oceanogr. 1995, 40, 1143-1152. [CrossRef]

68. Comber, S.; Gardner, M. Chromium redox speciation in natural waters. J. Environ. Monit. 2003, 5, 410-413. [CrossRef] [PubMed]

69. Pesavento, M.; Biezus, R.; Alberti, G.; Profumo, A.; D'Agostino, G. Speciation of copper(II) in natural waters in the presence of ligands of high and intermediate strength. Chem. Speciat. Bioavailab. 2004, 16, 35-43. [CrossRef]

70. Abualhaija, M.M.; Whitby, H.; van der Berg, C.M.G. Competition between copper and iron for humic ligands in estuarine waters. Mar. Chem. 2016, 172, 46-56. [CrossRef]

71. Boiteau, R.M.; Till, C.P.; Ruacho, A.; Bundy, R.M.; Hawco, N.J.; McKenna, A.M.; Barbeau, K.A.; Bruland, K.W.; Saito, M.A.; Repeta, D.J. Structural characterization of natural nickel and copper binding ligands along the US GEOTRACES Eastern Pacific Zonal Transect. Front. Mar. Sci. 2016, 3, 243. [CrossRef]

72. Lin, C. The chemical transformations of chromium in natural waters-A model study. Water Air Soil Poll. 2002, 139, 137-158. [CrossRef]

73. Meyers, P.A.; Leenheer, M.J.; Eadie, B.J.; Maule, S.J. Organic geochemists of suspended and settling particulate matter in Lake Michigan. Geochim. Cosmochim. Acta 1984, 48, 443-452. [CrossRef] 
74. Meyers, P.A.; Teranes, J.L. Textural analysis of lake sediments. In Tracking Environmental Change using Lake Sediments; Last, W.M., Smol, J.P., Eds.; Physical and Geochemical Methods; Kluwer Academic Publ.: Dordrecht, The Netherlands, 2001; Volume 2, pp. 41-82.

75. Håkanson, L. The importance of lake morphometry and catchment characteristics in limnology-Ranking based on statistical analyses. Hydrobiologia 2005, 541, 117-137. [CrossRef]

76. Meyers, P.A.; Ishiwatari, R. Lacustrine organic geochemistry-An overview of indicators of organic matter sources and diagenesis in lake sediments. Org. Geochem. 1993, 20, 867-900. [CrossRef]

77. Larsen, S.; Andersen, T.; Hessen, D.O. Predicting organic carbon in lakes from climate drivers and catchment properties. Glob. Biogeochem. Cycle 2011, 25. [CrossRef]

78. Elder, J.F. Metal Biogeochemistry in Surface-Water Systems: A Review of Principles and Concept; U.S. Geological Survey Circular: Reston, VA, USA, 1988; p. 50.

79. Last, W.M. Sediment organic matter. In Tracking Environmental Change using Lake Sediments. Physical and Geochemical Methods; Last, W.M., Smol, J.P., Eds.; Kluwer Academic Publ.: Dordrecht, The Netherlands, 2001; Volume 2, pp. 239-270.

80. Baudo, R.; Gisey, J.P.; Muntau, H. Sediments: Chemistry and Toxicity of in-Place Pollutants; Lewis Publ. Inc.: Chelsea, MA, USA, 1990; p. 405.

81. Blais, J.M.; Kalff, J. The influence of lake morphometry on sediment focusing. Limnol. Oceanogr. 1995, 40, 582-588. [CrossRef]

82. Yao, Q.; Wang, X.; Jan, H.; Chen, H.; Yu, Z. Characterization of the Particle Size Fraction associated with Heavy Metals in Suspended Sediments of the Yellow River. Int. J. Environ. Res. Public Health 2015, 12, 6725-6744. [CrossRef] [PubMed]

83. Chatkraborty, P.; Chatkraborty, S.; Vudamala, K.; Sarkar, A.; Nath, B.N. Partitioning of metals in different binding phases of tropical estuarine sediments: Importance of metal chemistry. Environ. Sci. Pollut. Res. 2016, 23, 3450-3462. [CrossRef] [PubMed]

84. Hsu, L.-C.; Huang, C.-Y.; Chuang, Y.-H.; Chen, H.-W.; Chan, Y.-T.; Teah, H.Y.; Chen, T.-Y.; Chang, C.-F.; Liu, Y.-T.; Tzou, Y.-M. Accumulation of heavy metals and trace elements in fluvial sediments received effluents from traditional and semiconductor industries. Sci. Rep. 2016, 6, 34250. [CrossRef] [PubMed]

85. Issaka, S.; Ashraf, M.A. Impact of soil erosion and degradation on water quality: A review. Geol. Ecol. Landsc. 2017, 1, 1-11. [CrossRef]

86. Nearing, M.A. Potential changes in rainfall erosivity in the U.S. with climate change during the 21st century. J. Soil Water Conserv. 2001, 56, 229-232.

87. Burt, T.; Boardman, J.; Foster, I.; Howden, N. More rain; less soil: Long-term changes in rainfall intensity with climate change. Earth Surf. Process Landf. 2016, 41, 563-566. [CrossRef]

88. Church, M. Mountains and montane channels. In Sediment Cascades: An Integrated Approach; Burt, T., Allison, R., Eds.; Wiley-Blackwell: Chichester, UK, 2010; p. 482.

89. Schiefer, E.; Petticrew, E.L.; Immell, R.; Hassan, M.A.; Sonderegger, D.L. Land use and climate change impacts on lake sedimentation rates in western Canada. Anthropocene 2013, 3, 61-71. [CrossRef]

90. Rose, N.L.; Morley, D.; Appleby, P.G.; Battarbee, R.W.; Alliksaar, T.; Guilizzoni, P.; Jeppesen, E.; Korhola, A.; Punning, J.-M. Sediment accumulation rates in European lakes since AD 1850: Trends; reference conditions and exceedance. J. Paleolimnol. 2011, 45, 447-468. [CrossRef]

91. Lami, A.; Cameron, N.; Korhola, A. Palaeolimnology and ecosystem dynamics at remote European Alpine lakes (mountain lakes research programme; MOLAR). J. Limnol. 2000, 59 (Suppl. 1), 109-119.

92. Schindler, D.W. The cumulative effects of climate warming and other stresses on Canadian freshwaters in the new millennium. Can. J. Fish. Aquat. Sci. 2001, 58, 18-29. [CrossRef]

93. Magnuson, J.J.; Robertson, D.M.; Benson, B.J.; Wynne, R.H.; Livingstone, D.M.; Arai, T.; Assel, R.A.; Barry, R.G.; Card, V.; Kuusisto, E.; et al. Historical trends in lake and river ice cover in the northern hemisphere. Science 2000, 289, 1743-1746. [CrossRef] [PubMed]

94. Bunting, L.; Leavitt, P.R.; Gibson, C.E.; McGee, E.J.; Hall, V.A. Degradation of water quality in Lough Neagh; Northern Ireland; by diffuse nitrogen flux from a phosphorus-rich catchment. Limnol. Oceanogr. 2007, 52, 354-369. [CrossRef]

95. Weyhenmeyer, G.A.; Karlsson, J. Nonlinear response of dissolved organic carbon concentrations in boreal lakes to increasing temperatures. Limnol. Oceanogr. 2009, 54, 2513-2519. [CrossRef] 
96. Mintz, M. Variability of Lacustrine Sediment Proxy Responses to Late Holocene Climate Change as Modified by Lake Specific Processes: A Review of Ecological and Geophysical Processes across Northern and Eastern Iceland. Independent Study Project (ISP) 2016; Collection 2446. Available online: http:/ / digitalcollections. sit.edu/isp_collection/2446 (accessed on 25 July 2017).

97. Guilizzoni, P.; Lami, A.; Manca, M.; Musazzi, S.; Marchetto, A. Palaeoenvironmental changes inferred from biological remains in short lake sediment cores from the central Alps and Dolomites. Hydrobiologia 2006, 562, 167-191. [CrossRef]

98. Schwörer, C.; Henner, P.D.; Tinner, W. A model-data comparison of Holocene timberline changes in the Swiss Alps reveals past and future drivers of mountain forest dynamics. Glob. Chang. Biol. 2014, 20, 1512-1526. [CrossRef] [PubMed]

99. Grace, J.; Berninger, F.; Nagy, L. Impacts of climate change on the tree line. Ann. Bot. 2002, 90, 537-544. [CrossRef] [PubMed]

100. Gehrig-Fasel, J.; Guisan, A.; Zimmermann, N.E. Tree line shifts in the Swiss Alps: Climate change or land abandonment? J. Veg. Sci. 2007, 18, 571-582. [CrossRef]

101. Morgan, R.P.C.; Quinton, J.N.; Smith, R.E.; Govers, G.; Poesen, J.W.A.; Auerswald, K.; Chisci, G.; Torri, D.; Styczen, M.E. The European soil erosion model (EUROSEM): A dynamic approach for predicting sediment transport from fields and small catchments. Earth Surf. Process. Landf. 1998, 23, 527-544. [CrossRef]

102. Cakula, A.; Ferreira, V.; Panagopoulos, T. Dynamic Model of Soil Erosion and Sediment Deposit in Watersheds. In Recent Researches in Environment, Energy Systems and Sustainability, Proceedings of the 8th WSEAS International Conference on Energy; Environment; Ecosystems and Sustainable Development (EEESD '12), Faro, Portugal, 2-4 May 2012; pp. 33-38, ISBN 978-1-61804-088-6.

103. Haeberli, W.; Beniston, M. Climate change and its impacts on glaciers and permafrost in the Alps. Ambio 1998, 27, 258-265.

104. Boeckli, L.; Brenning, A.; Gruber, S.; Noetzli, J. Permafrost distribution in the European Alps: Calculation and evaluation of an index map and summary statistics. Cryosphere 2012, 6, 807-820. [CrossRef]

105. Viers, J.; Dupre, B.; Gaillardet, J. Chemical composition of suspended sediments in world rivers: New insights from a new database. Sci. Total Environ. 2009, 407, 853-868. [CrossRef] [PubMed]

106. Leonelli, G.; Pelfini, M.; Morra di Cella, U. Detecting climatic treelines in the Italian Alps: The influence of geomorphological factors and human impacts. Phys. Geogr. 2009, 30, 338-352. [CrossRef]

107. Rosén, P.; Hammarlund, D. Effects of climate; fire and vegetation development on Holocene changes in total organic carbon concentration in three boreal forest lakes in northern Sweden. Biogeosciences 2007, 4, 975-984. [CrossRef]

108. Tian, G.; He, H.; Cheng, W.; Bai, Z.; Wang, Y.; Zhang, X. Factors controlling soil organic carbon stability along a temperate forest altitudinal gradient. Nat. Sci. Rep. 2016, 6, 18783. [CrossRef] [PubMed]

109. Crosa, G.; Castelli, E.; Gentili, G.; Espa, P. Effects of suspended sediments from reservoir flushing on ish and macroinvertebrates in an alpine stream. Aquat. Sci. 2010, 72, 85-95. [CrossRef]

(C) 2017 by the authors. Licensee MDPI, Basel, Switzerland. This article is an open access article distributed under the terms and conditions of the Creative Commons Attribution (CC BY) license (http://creativecommons.org/licenses/by/4.0/). 